\title{
FOREST COMPOSITION, FUELWOOD HARVEST AND REGENERATION STATUS IN FOUR COMMUNITY FORESTS OF CENTRAL NEPAL
}

\author{
Ghanashyam Subedi*, Binod Khatiwada*, Sandesh Bhattarai** and Kamal Prasad Acharya \\ *Central Department of Environmental Sciences, Tribhuvan University, Kirtipur, Kathmandu, Nepal. \\ **Central Department of Botany, Tribhuvan University, Kirtipur, Kathmandu, Nepal.
}

\begin{abstract}
Present study aims to explore forest composition, fuelwood harvest and regeneration status in two community forests of central Nepal. We carried out our study in different periods of 2007 and 2008 . Household surveys were conducted to find the condition of fuelwood harvest and people dependency on community forest. Community forests of Nawalparasi districts are dominated by Shorea robusta whereas community forests of Syanja district are dominated by Castanopsis indica and Schima wallichii with highest IVI value. Percapita fuelwood consumption and domestic animals are higher in Nawalparasi district than in Syanja district. Grasses are the main source of fodder in Nawalparasi district whereas trees in Syanja district. Farmland is the main source for fodder in both the districts but even higher in Syanja district. For fuelwood people depend on forest than the farmland. Dominant tree species in Patapati Lulpani Community Forest (PLCF) showed reverse J-shaped size class distribution indicating sustainable regeneration whereas dominant tree species in Gamtam Community Forest (GCF), Dhuseri Community Forest (DCF) and Bhedawari Community Forest (BCF) showed poor regeneration status.
\end{abstract}

Key words: Community forest; Forest composition; Fuelwood harvest; Regeneration.

\section{INTRODUCTION}

Forest cover extensive areas in different landscapes throughout the world and are of fundamental importance to their biodiversity, functionally and socioeconomic value (Kreyer and Zerbe 2006). Forest and people have been and still are intimately connected, socially as well as economically. Fuelwood is one of major source of energy accounting about $7 \%$ of total energy supply (FAO 2006). In the developing country like Nepal, fuelwood is already the primary source (about 80\%) of energy supply. The process of exploiting forest resources beyond the sustainable capacity has lead to a number of environmental problems such as loss of habitat and biodiversity (Chaudhary 2000, GoN/MFSC 2009). Nepal is not an exception. With the ever higher prices of fuels, there will be even more pressure on forests.

The Government of Nepal has introduced a scheme of community forest development project to improve and reestablish forests so as to increase the supply of fuel wood, fodder and timber. Community forestry of Nepal is a more success story in terms of expansion on the forest cover area on the one hand and conservation of biodiversity on the other (Kanel 2004, Baniya 2006). In the community forestry people mutually specify their use rights to the management, development and utilization of forest resources. In order to collect more revenue from community forests, the community forest user groups are running silvicultural and harvesting activities (Acharya et al. 2006). Instead of growing all plant species in their forests, people are now focusing to few selected fast growing species. The practice of using a few selected tree species for fuelwood and absolute conservation of dominant species in community managed forests may affect the regeneration process and community structure of forests.

Natural regeneration is the process of re-growing or reproduction of plants by their juvenile. It is important not only for the reproductive role but also for ensuring the replacement of any member of a community that dies off after completing life cycle (Fatubarin 1987). Population structure, characterized by the presence of sufficient population of seedlings, saplings and young trees indicate a successful regeneration of forest species (Saxena et al. 1984). Regeneration pattern determines the species composition and stability in the future. Natural regeneration is a slow process but important to maintain a stable age structure in any plant community. Undisturbed old growth forest with sustainable regeneration found to have a reverse J-shaped size- class distribution (West et al. 1981). A bell shaped size-class distribution has been attributed to disturbed forest where

Author for Correspondence: Kamal Prasad Acharya, P.O. Box 15142 KPC 676, Kathmandu, Nepal. E-mail: acharya.kamal@gmail.com. 
regeneration is hampered (Saxena et al. 1984). Majority of studies on community forestry programs of Nepal are carried out on their successful side of management and successful collection of revenue (see Dahal and Masuda 2007), however, there is the lack of study on quantitative study on fuelwood harvest and regeneration process happening in community forests. Therefore, present study will be helpful to find out the quantitative estimation of forest products harvest, and regeneration status of community forests. We conducted present research: (i) to quantify the forest composition of the study areas, (ii) to identify the major sources of fuelwood supply within the study area, and (iii) to study the status of natural regeneration patterns of dominant tree species.

\section{MATERIALS AND METHODS}

\section{Study area}

This study covers four community forests, each with two community forests of Nawalparasi district and Syangja district. Dhuseri Community Forest (DCF) lies in Rajahar VDC and Bhedawari Community Forest (BCF) lies in Mukundapur VDC of Nawalparasi district whereas Patapati Lulpani Community Forest (PLCF) and Gamtam Community Forest (GCF) lie in ward number 10 and 11 of Putalibazar Municipality of Syangja district (Figure 1). The DCF, BCF, PLCF and GCF have been protected since 12 years, two years, 13 years and three years ago respectively.

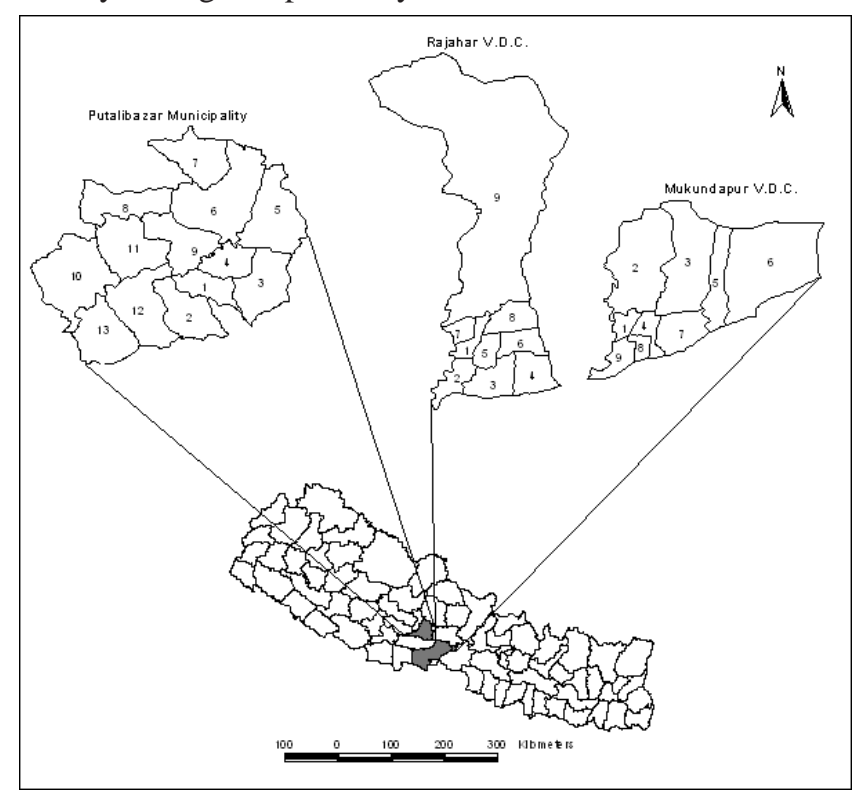

Figure 1: Map of the study area.

\section{Vegetation and ethnic composition}

The DCF and BCF are dominated by Sal (Shorea robusta) and associated species are Terminalia alata, Terminalia bellirica, Semecarpus anacardium, Rhus species etc. Theses sites are inhabited mainly by three ethnic groups: Tharus, Brahmins and Chhetris. A number of other ethnic groups like Moosahar, Darai, Magar, Newa, Damai, Kami, etc. are also found. The Tharus live in dense clusters of their own group, but each cluster generally constituted with Brahmins, Chhetris or other ethnic groups. The PLCF and GCF are dominated by dominated by Castanopsis indica and Schima wallichii and other associated species are Sapium insigne, Diospyros malabarica, Myrica esculenta and Syzygium cumini etc. These sites are inhabited mainly by Brahmin, Chhetri, Gurung, Magar, Kami, Damai and Sarkis.

\section{Household survey}

Using structure questionnaire, household surveys ( $>10 \%$ of total) were carried out in each village. All ethnic groups and economic classes were proportionately represented in the samples. We noted the number of domestic animals per capita, per capita fuelwood consumption (kg/person/year), fodder type (grass and tree) and proportion of total supply of tree fodder and fuelwood derived from forest and farmland.

\section{Forest sampling}

We used 10m x 10m quadrat for vegetation and regeneration study. All together 32 quadrats were laid: each community forest with eight quadrats. In each quadrat, we counted the number of trees $(\mathrm{dbh}>10 \mathrm{~cm})$ and measured their diameter (dbh at $137 \mathrm{~cm}$ above the ground level). All the tree species were divided into dbh classes of $10 \mathrm{~cm}$ intervals, giving a total of 8 size classes. We counted all the saplings (height $>137 \mathrm{~cm}$ and $\mathrm{dbh}<10 \mathrm{~cm}$ ) and seedlings (height $<137 \mathrm{~cm}$ and $\mathrm{dbh}=0$ $\mathrm{cm})$ within the quadrat. We identified the collected plants with the help of Polunin and Stainton (2000) and Stainton (1997). Nomenclature of the identified species follows Press et al. (2000). We calculated density $\left(\mathrm{ha}^{-1}\right)$, frequency (\%), basal area $\left(\mathrm{m}^{2} \mathrm{ha}^{-1}\right)$, their relative values and Important Value Index (IVI) following Zobel et al. (1987).

\section{Statistical analysis and graphical representation}

We used $\mathrm{R}_{2.8 .1}$ (R Development Core Team 2008) for graphical representations.

\section{RESULTS AND DISCUSSION}

\section{Forest composition in community forests of Syanja district}

Altogether 10 and 11 species of tree were recorded from GCF and PLCF respectively (Table 1 and 2). Some of the plant species were unidentified so local name are given in tables by asterisk. This study showed Catasnopsis indica as the most dominant species with IVI value 114.24 in GCF and 120.05 in PLCF. Similarly, Schima wallichhi, a co-dominant species in both forests with IVI value 83.18 for GCF and 88.51 in PLCF (Table 1 \& 2). The existence of Castanipsis-Schima dominance in this altitude is similar with the findings by Paudel (2003) at an elevation of 1000 to $3000 \mathrm{~m}$ a.s.l. The PLCF is denser in comparison to GCF which is recently declared as community forest.

\section{Forest composition in community forests of Nawalparasi dis- trict}

Altogether 13 and nine species of tree were recorded from DCF and BCF respectively (Table 3 and 4). The unidentified species were marked with asterisk. This study showed Shorea robusta as the most dominant species with IVI value 102.45 in DCF and 99.79 in BCF. Similarly, Mallotus philippensis, 
Table 1: Importance value index of tree species in Gamtam Community Forest (GCF)

\begin{tabular}{|c|c|c|c|c|c|c|c|c|}
\hline S.N. & Name of species & $\begin{array}{l}\text { Density } \\
\text { (pl/ha) }\end{array}$ & $\begin{array}{l}\mathrm{RD} \\
(\%)\end{array}$ & $\begin{array}{c}\text { Frequency } \\
\text { (\%) }\end{array}$ & $\begin{array}{l}\mathrm{RF} \\
(\%)\end{array}$ & $\begin{array}{c}\text { Basal Area } \\
\left(\mathrm{m}^{2} / \mathrm{ha}\right)\end{array}$ & $\begin{array}{l}\text { RBA } \\
(\%)\end{array}$ & IVI \\
\hline 1 & Castanopsis indica & 383.33 & 45.77 & 100 & 29.62 & 23.72 & 38.84 & 114.24 \\
\hline 2 & Schima wallichii & 216.66 & 25.87 & 100 & 29.62 & 16.91 & 27.68 & 83.18 \\
\hline 3 & Sapium insigne & 50 & 5.97 & 37.5 & 11.11 & 5.33 & 8.72 & 25.80 \\
\hline 4 & Diospyros malabarica & 33.33 & 3.97 & 25 & 7.40 & 3.5 & 5.73 & 17.11 \\
\hline 5 & Myrica esculenta & 25 & 2.98 & 12.5 & 3.70 & 3.5 & 5.73 & 12.41 \\
\hline 6 & Syzygium cumini & 25 & 2.98 & 12.5 & 3.70 & 2.16 & 3.53 & 10.22 \\
\hline 7 & Ratopate* & 37.5 & 4.47 & 12.5 & 3.70 & 3.43 & 5.61 & 13.79 \\
\hline 8 & Bombax ceiba & 25 & 2.98 & 12.5 & 3.70 & 1.02 & 1.67 & 8.35 \\
\hline 9 & Cleyera ochnacea & 25 & 2.98 & 12.5 & 3.70 & 0.75 & 1.22 & 7.91 \\
\hline 10 & Damauro* & 16.66 & 1.98 & 12.5 & 3.70 & 0.75 & 1.22 & 6.92 \\
\hline
\end{tabular}

*Local name of a species

Table 2: Importance value index of tree species in Patapati Lulpani Community Forest (PLCF)

\begin{tabular}{|c|l|c|c|c|c|c|c|c|}
\hline S.N. & Name of species & $\begin{array}{c}\text { Density } \\
(\mathrm{pl} / \mathrm{ha})\end{array}$ & $\begin{array}{c}\text { RD } \\
(\%)\end{array}$ & $\begin{array}{c}\text { Frequency } \\
(\%)\end{array}$ & $\begin{array}{c}\text { RF } \\
(\%)\end{array}$ & $\begin{array}{c}\text { Basal Area } \\
\left(\mathrm{m}^{2} / \mathrm{ha}\right)\end{array}$ & RBA (\%) & IVI \\
\hline 1 & Castanopsis indica & 500 & 49.38 & 100 & 25 & 72.05 & 45.67 & 120.05 \\
\hline 2 & Schima wallichii & 312.5 & 30.86 & 100 & 25 & 51.51 & 32.65 & 88.51 \\
\hline 3 & Syzygium cumini & 37.5 & 3.70 & 37.5 & 9.37 & 7.16 & 4.53 & 17.61 \\
\hline 4 & Toona ciliata & 12.5 & 1.23 & 12.5 & 3.12 & 2.87 & 1.81 & 6.17 \\
\hline 5 & Ghokre* & 12.5 & 1.23 & 12.5 & 3.12 & 2 & 1.26 & 5.62 \\
\hline 6 & Ratopate* & 25 & 2.46 & 25 & 6.25 & 4.17 & 2.64 & 11.36 \\
\hline 7 & Cleyera ochnacea & 37.5 & 3.70 & 37.5 & 9.37 & 4.58 & 2.90 & 15.98 \\
\hline 8 & Myrica esculenta & 12.5 & 1.23 & 12.5 & 3.12 & 2.87 & 1.81 & 6.17 \\
\hline 9 & Shorea robusta & 37.5 & 3.70 & 37.5 & 9.37 & 7.56 & 4.79 & 17.87 \\
\hline 10 & Rhus sp. & 12.5 & 1.23 & 12.5 & 3.12 & 1.57 & 0.99 & 5.35 \\
\hline 11 & Rhododendron arboreum & 12.5 & 1.23 & 12.5 & 3.12 & 1.4 & 0.88 & 5.24 \\
\hline
\end{tabular}

*Local name of a species

Terminalia bellirica and T. alata are co-dominant species in both forests (Table $3 \& 4$ ). The existence of Shorea robusta and Mallotus philippensis dominance was reported by Giri et al. (2003) at an elevation of 100 to $1400 \mathrm{~m}$ a.s.l. in Royal Bardiya National Park. The older community forest (DCF) is denser than the newer one (BCF).

\section{Household survey and fuelwood consumption in Syanja District}

A total 180 household (821 people) and 218 household (1100 people) are in PLCF and GCF respectively which are the forest user groups. Most of them depend on traditional agricultural system. The average family size was 5 persons in both the community forest. More than 98\% household sampled in

Table 3: Importance value index of tree species in Dhuseri Community Forest (DCF)

\begin{tabular}{|c|c|c|c|c|c|c|c|c|}
\hline S.N. & Name of species & $\begin{array}{l}\text { Density } \\
\text { (pl/ha) }\end{array}$ & $\begin{array}{l}\mathrm{RD} \\
(\%)\end{array}$ & $\begin{array}{c}\text { Frequency } \\
(\%)\end{array}$ & $\begin{array}{l}\mathrm{RF} \\
(\%)\end{array}$ & $\begin{array}{c}\text { Basal Area } \\
\left(\mathrm{m}^{2} / \mathrm{ha}\right)\end{array}$ & RBA (\%) & IVI \\
\hline 1 & Shorea robusta & 624 & 30.64 & 100 & 12.34 & 68.3 & 59.46 & 102.45 \\
\hline 2 & Terminalia alata & 175 & 8.59 & 100 & 12.34 & 8.95 & 7.79 & 28.73 \\
\hline 3 & Terminalia bellirica & 200 & 9.82 & 80 & 9.87 & 7.16 & 6.23 & 25.93 \\
\hline 4 & Syzygium cumini & 200 & 9.82 & 80 & 9.87 & 3.11 & 2.70 & 22.40 \\
\hline 5 & Semecarpus anacardium & 175 & 8.59 & 80 & 9.87 & 1.18 & 1.02 & 19.49 \\
\hline 6 & Mallotus philippensis & 237.5 & 11.66 & 100 & 12.34 & 10.23 & 8.90 & 32.91 \\
\hline 7 & Cassia fistula & 162.5 & 7.97 & 80 & 9.87 & 3.41 & 2.96 & 20.82 \\
\hline 8 & Bauhhinia purpurea & 62.5 & 3.06 & 50 & 6.17 & 2.87 & 2.49 & 11.74 \\
\hline 9 & Adina cordifolia & 75 & 3.68 & 50 & 6.17 & 4.7 & 4.09 & 13.94 \\
\hline 10 & Cleistocalyx operculatus & 37.5 & 1.84 & 30 & 3.70 & 1.12 & 0.97 & 6.52 \\
\hline 11 & Swida ablonga & 25 & 1.22 & 20 & 2.46 & 1.4 & 1.21 & 4.91 \\
\hline 12 & Rato kaioo* & 37.5 & 1.84 & 20 & 2.46 & 1.23 & 1.07 & 5.38 \\
\hline 13 & Chai chui* & 25 & 1.22 & 20 & 2.46 & 1.19 & 1.03 & 4.73 \\
\hline
\end{tabular}


Table 4: Importance value index of tree species in Bhedawari Community Forest (BCF)

\begin{tabular}{|c|l|c|c|c|c|c|c|c|}
\hline S.N. & Name of species & $\begin{array}{c}\text { Density } \\
(\mathrm{pl} / \mathrm{ha})\end{array}$ & $\begin{array}{c}\text { RD } \\
(\%)\end{array}$ & $\begin{array}{c}\text { Frequency } \\
(\%)\end{array}$ & $\begin{array}{c}\text { RF } \\
(\%)\end{array}$ & $\begin{array}{c}\text { Basal Area } \\
\left(\mathrm{m}^{2} / \mathrm{ha}\right)\end{array}$ & RBA (\%) & IVI \\
\hline 1 & Shorea robusta & 279 & 24.93 & 100 & 17.02 & 67.34 & 57.83 & 99.79 \\
\hline 2 & Terminalia alata & 123 & 10.99 & 100 & 17.02 & 10.12 & 8.69 & 36.70 \\
\hline 3 & Terminalia bellirica & 112 & 10.01 & 75 & 12.76 & 9.74 & 8.36 & 31.14 \\
\hline 4 & Syzygium cumini & 89.23 & 7.97 & 75 & 12.76 & 4.11 & 3.52 & 24.27 \\
\hline 5 & Semecarpus anacardium & 74.6 & 6.66 & 62.5 & 10.63 & 2.38 & 2.04 & 19.34 \\
\hline 6 & Mallotus philippensis & 209.3 & 18.70 & 87.5 & 14.89 & 16.72 & 14.35 & 47.95 \\
\hline 7 & Cassia fistula & 145.2 & 12.97 & 37.5 & 6.38 & 3.45 & 2.96 & 22.32 \\
\hline 8 & Rato kaioo* & 47.7 & 4.26 & 25 & 4.25 & 1.27 & 1.09 & 9.60 \\
\hline 9 & Chai chui* & 38.8 & 3.46 & 25 & 4.25 & 1.31 & 1.12 & 8.84 \\
\hline
\end{tabular}

*Local name of a species

a survey used fuelwood for coking food and animal feed (Kudo). Some of the people nowadays have biogas plant but very few have liquefied petroleum gas (LPG) cylinders. In PLCF and GCF people collect firewood during thinning practices of forest, felling old trees and distribute it proportionally. Some ethnic groups like Magars, Damais, Sarkis need large amount of fuelwood to make alcohol (raksi). For fuelwood, people dependency on forest is higher in PLCF ( $80 \%$ of the total supply) than in GCF ( $45 \%$ of the total supply) (Figure 2). In GCF, fuelwood collection is higher from farmland (55\% of the total supply) than from forest (45\% of the total supply) (Figure 2). Per capita fuelwood consumption is $262.5 \mathrm{~kg} /$ person/ year in PLCF and and $226 \mathrm{~kg} /$ person/ year in GCF (Figure 3b). Per capita domestic animals are 2.34 and 1.89 in PLCF and GCF respectively (Figure 3a). Regarding fodder type, grass and tree constitute same proportion in PLCF whereas in GCF, $60 \%$ of the fodder is fulfilled from trees and $40 \%$ from grass (Figure 4). Supply of tree fodder from agricultural land is highest in both the community forests (78\% in PLCF and 81\% in GCF) than from forests (22\% in PLCF and 19\% in GCF) (Figure 5).
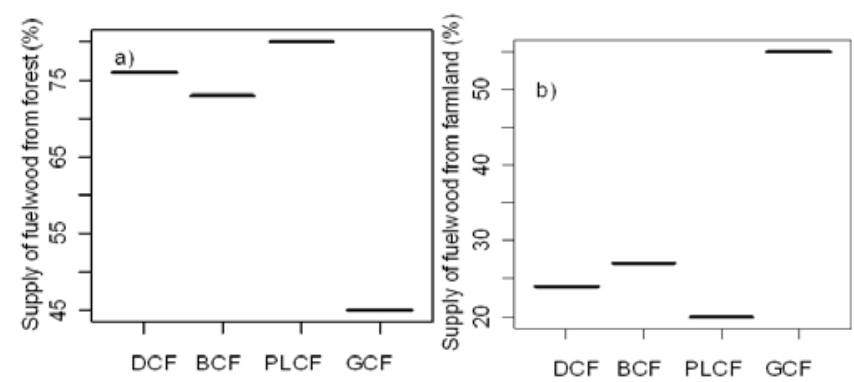

Figure 2: Supply of fuelwood in four community forests.
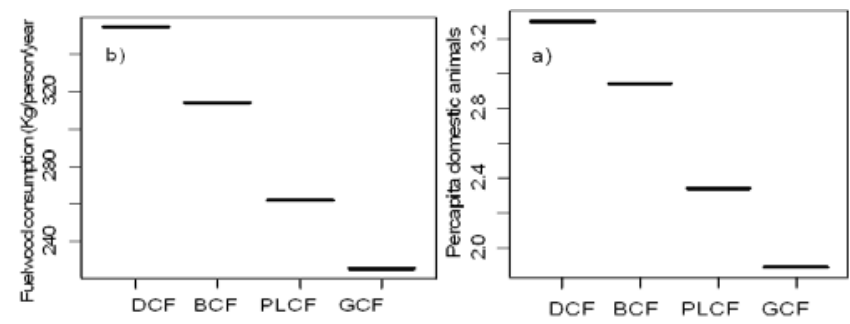

Figure 3: Graph showing a) Per capita domestic animals and b) fuelwood consumption in four community forests.
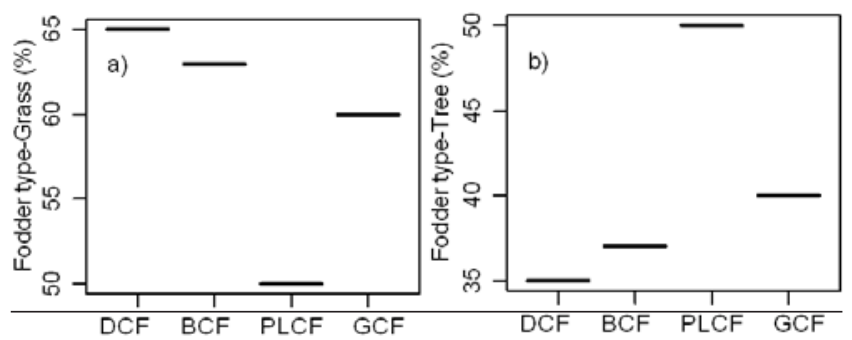

Figure 4: Type of fodder a) grass b) tree in four community forest.

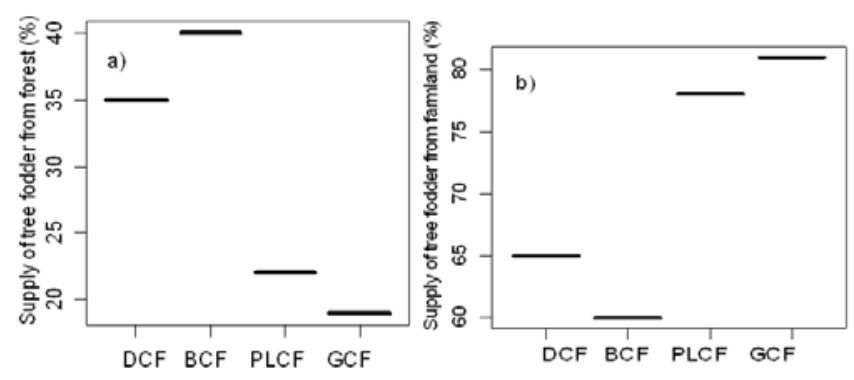

Figure 5: Supply of fodder from a) forest and b) farmland in four community forests.

\section{Household survey and fuelwood consumption in Nawalparasi District}

A total 715 households in Rajahar VDC (DCF) and 736 households in BCF are associated with community forests. Most of them depend on traditional agricultural system. The average family size was five and six in DCF and BCF respectively. People collect firewood during thinning practices of forest, felling old trees and distribute it proportionally. For fuelwood, people dependency on forest is higher in both the community forests (76\% of the total supply in DCF and 73\% of the total supply in BCF) than on farmland (24\% of the total supply in DCF and 27\% of the total supply in BCF) (Figure 2). Per capita fuelwood consumption was $354.6 \mathrm{~kg} /$ person/ year in DCF and 314 kg/person/year in BCF (Figure 3b). Per capita domestic animals were 3.3 and 2.94 in DCF and BCF respectively (Figure 3a). Regarding fodder type, grass constitutes proportion (65\% of the total supply in DCF and $63 \%$ of the total supply in BCF) than trees (35\% of the total supply in DCF and 37\% of the total supply in BCF) (Figure 4). Supply of tree fodder from agricultural/farm land was higher in both the community forests (65\% of the total supply in DCF and $60 \%$ of the total supply in BCF) than from forests (35\% of the 
total supply in DCF and $40 \%$ of the total supply in BCF) (Figure 5).

\section{REGENERATION}

The size class distribution of $S$. robusta in both the Community forests of Nawalparasi district showed lack of sustainable regeneration (Figure 6a). There was absence of trees of size classes $20-30 \mathrm{~cm}$ and higher dbh classes. In case of community forests of Syanja district, C. indica and S. wallichii in GCF indicates bell shaped size class distribution diagram and this is the indication of poor regeneration (Vetaas 2000). But, C. indica and S. wallichii in PLCF indicates reverse Jshaped structure and this is the indication of sustainable regeneration (Figure 6b) (Acharya et al. 2007, Shrestha 2005). Regarding seedlings and saplings, higher numbers of seedlings and saplings are observed in the community forests which are protected since longer time (DCF and PLCF) (Figure $7 \mathrm{a}$ and $7 \mathrm{~b})$.
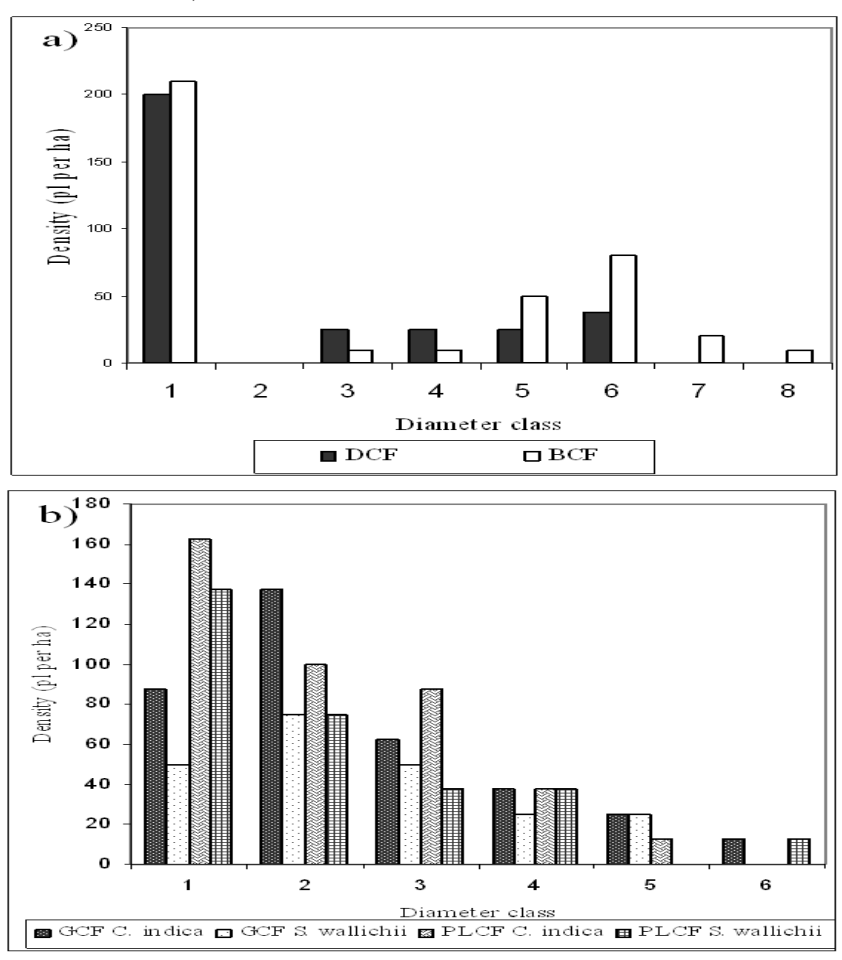

Figure 6: DBH size class distributions of dominant tree species a) S. robusta in Nawalparasi district and b) C. indica and S. wallichii in Syanja district.

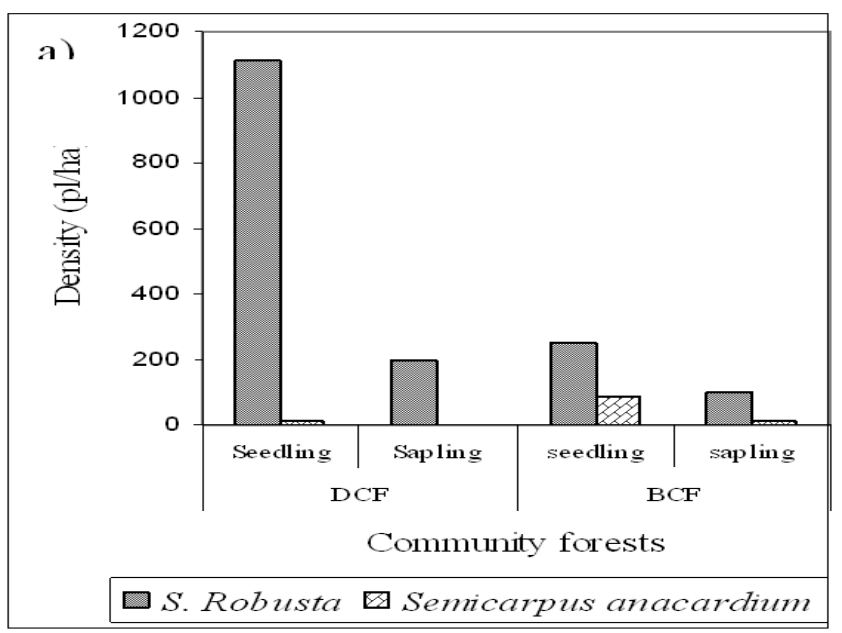

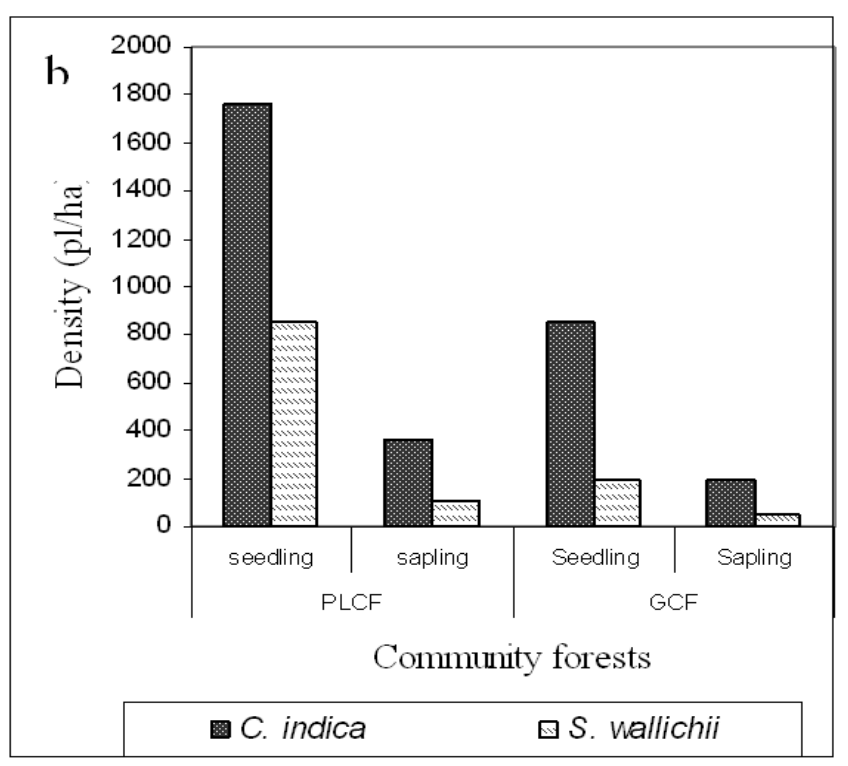

Figure 7: Seedlings and Saplings of dominant tree species in a) Nawalparasi district and b) Syanja district.

\section{CONCLUSION}

Community forests of Nawalparasi district (BCF and DCF) are dominated by $S$. robusta, whereas, community forests of Syanja district (PLCF and GCF) are dominated by C. indica and S. wallichii. For fuelwood, majority of people depend more on forest. However, in GCF people depend more on farmland for fuelwood. Per capita fuelwood consumption is higher in community forests of Nawalparasi district than in Syanja district. Supply of tree fodder in all the community forests is higher from farmland than from forests. In three out of four community forests, major fodder is grass. Although the forests are managed by community forest user groups, there is poor regeneration of S. robusta in GCF and BCF and C. indica and S. wallichii in GCF. However, there is good regeneration of dominant tree species in PLCF. In all the community forests, higher number of seedlings and saplings are observed in older community forests.

\section{ACKNOWLEDGEMENTS}

We (GS \& BK) are thankful to Prof. UKR Yadav, Head of Central Department of Environmental Studies for providing necessary administrative help during our field trip. Thank goes to local respondents of the community forests for their help during our field trip and sharing valuable informations. We thank to anonymous referee for his/her valuable comments on the manuscript.

\section{REFERENCES}

Acharya, K.P., Khadka, S., Lekhak, H.D., Chaudhary, R.P. and Vetaas, O.R. 2007. Species composition and regeneration of coniferous forest in Manang. In Local effects of Global Changes in the Himalayas: Manang, Nepal (eds.) Chaudhary, RP, TH Aase, OR Vetaas and BP Subedi. Tribhuvan University, Nepal and University of Bergen, Norway. P. 199 (total p. 223).

Acharya, K.P., Goutam, K.R., Nepal, B.K. and Gautam, G. 2006. Participatory assessment of biodiversity conservation in community forestry in Nepal. Banko Jankari. 16: 46-56.

Baniya, A. 2006. Household characteristics and perception of users towards the environmental changes within community forests in 
the Dhaulagiri hills of Nepal. Banko Jankari. 16: 35-40.

Chaudhary, R.P. 2000. Forest conservation and environmental management in Nepal: a review. Biodiversity and Conservation. 9: $1235-1260$.

Dhakal, M. and Masuda, M. 2007. Generation and utilization of community fund in small-scale community forest management in the Terai region of Nepal. Banko Jankari. 17: 55-61.

FAO, 2006. Wood Energy. In: http://www.fao.org/forestry/14011/en/ (accessed on 9 August 2009).

Fatubarin, A. 1987. Observation on the natural regeneration of the woody plants in a Savana ecosystem in Nigeria. Tropical Ecology. 28: $1-8$.

Giri, A., Aryal, B., Ghimire, S.K., Shrestha, K.K. and Jha, P.K. 2001. Vegetation composition and biomass production in riverine forest of Royal Bardia National Park, Nepal. Nepal Journal of Science and Technology. 3: 33-40.

GoN/MFSC. 2009. Nepal Fourth National Report to the Convention Biological Diversity. Ministry of Forest and Soil Conservation, Government of Nepal, Kathmandu, Nepal.

Kreyer, D. and Zerbe, S. 2006. Short-lived tree species and their role as indicators for plant diversity in the restoration of natural forests. Restoration Ecology. 14: 137-147.

Kanel, K. 2004. Twenty five years of community forestry: contribution to millennium development goals. In Twenty five years of community forestry: contributing to millennium development goal (eds.) Kanel, KR, P Mathema, BR Kanel, DR
Niraula, AR Sharma and M Gautam. Proceedings of fourth national workshop on community forestry, 4-6 August, 2004, Kathmandu. Paudel, S. 2003. Vegetation and prominent flora from Begnas tal to Tara hill, Annapurna conservation area project, Kaski. Himalayan Journal of Sciences. 1: 43-46.

Polunin, O. and Stainton, A. 2000. Flowers of the Himalaya. Oxford University Press, New Delhi, India. P. 545.

Press, L., Shrestha, K.K. and Sutton, D.A. 2000. Annotated Checklist of the Flowering Plants of Nepal. The Natural History Museum, London.

Saxena, A.K., Singh, S.P. and Singh, J.S. 1984. Population structure of forests of Kumaun Himalaya: Implications for management. Journal of Environmental Management. 19: 307-324.

Shrestha, B.B. 2005. Forest harvest, management and regeneration of two community forests in Central Nepal. Himalayan Journal of Sciences. 3: 75-80.

Stainton, A. 1997. Flowers of the Himalaya: A Supplement. Oxford University Press, New Delhi, India. P. $72+128$ plates.

Vetaas, O.R. 2000. The effect of environmental factors on the regeneration of Quercus semecarpifolia Sm. in central Himalaya, Nepal. Plant Ecology. 146: 137-144.

West, D.C., Shugart, H.H. and Ranney, J.W. 1981. Population structure of forests over a large area. Forest Science. 27: 701-710.

Zobel, D.B., Jha, P.K., Behan, N.J. and Yadav, U.K.R. 1987. A Practical Manual for Ecology. Ratna Book Distributors, Kathmandu, Nepal. P. 150. 